\title{
ANALISIS SISTEM INFORMASI MANAJEMEN PENDIDIKAN \\ DALAM PERSPEKTIF HUMAN COMPUTER INTERACTION ( Studi Kasus Dinas Pendidikan Kabupaten Brebes )
}

\author{
Nur Khasan', Bambang Soedijono W A $\mathrm{A}^{2}$, Hanif Al Fatta ${ }^{3}$ \\ 1),2),3) Magister Teknik Informatika STMIK AMIKOM Yogyakarta \\ Email : hasanaji96@gmail.com ${ }^{1)}$, bambang.s@amikom.ac.id ${ }^{2)}$, \\ hanif.a@amikom.ac.id ${ }^{3)}$
}

\begin{abstract}
ABSTRAK
Penelitan ini bertujuan untuk menganalisis Sistem Informasi Manajemen Pendidikan (SIMDiK) Dinas Pendidikan Kabupaten Brebes dari sudut pandang Human Computer Interaction. Penelitian ini membahasan tentang efektivitas dan penerapannya dalam menyajikan dan mengelola data pendidikan juga variabel yang berpengaruh terhadap efektivitas Sistem Informasi Manajemen Pendidikan (SIMDiK) Dinas pendidikan kabupaten Brebes.Objek penelitian ini adalah Sistem Indormasi Manajemen Pendidikan ( SIMDiK ) Dinas Pendidikan Kabupaten Brebes.Metode analisis yang dipilih adalah Regresi Linear bergandadengan bantuan software SPSS Versi 22 yang digunakan untuk menguji hipotesis H1 hingga H5.Jenis penelitian yang dilakukan adalah penelitian asosiatif kausal. Penelitian asosiatif kausal adalah penelitian yang bertujuan untuk menganalisis hubungan antara satu variabel dengan variabel lainya.Pengumpulan data dilakukan dengan menggunakan kuesioner. Skala pengukuran dalam kuesioner memakai model skala Likert, yaitu skala yang dipakai untuk mengukur pendapat atau persepsi seseorang atau sekelompok orang.Jawaban diberi penilaian dari 1 sampai 5 Tanggapan yang paling positif (sangat setuju) diberi nilai paling besar dan tanggapan paling negatif (sangat tidak setuju) diberi nilai paling kecil.Hasil pengujian menunjukkan bahwa pengaruh Learnability, Efficiency, Memorability, Errors, Satisfaction terhadap Usability pada Sistem Informasi Manajemen Pendidikan ( SIMDiK ) Dinas Pendidikan Kabupaten Brebes adalah signifikan.Berdasarkan hasil jawaban rata-rata jawaban responden adalah sebesar 4,02 atau berkategori tinggi..maka sistem informasi manajemen pendidikan (SIMDiK)dinas pendidikan kabupaten Brebes sudah efektif.Namun variabel Learnability dan Errors berpengaruh negatif secara parsial.
\end{abstract}

Kata Kunci : HCI, Usability,Learnability, Efficiency, Memorability, Errors, Satisfaction

Jurnal Telematika Vol 9 No. 2 Agustus 2016 


\section{LATAR BELAKANG}

Sistem informasi dibangun dengan syarat-syarat tertentu yang harus dipenuhi sehingga sistem informasi tersebut sistem informasi tersebut bisa dikatakan sukses, Syarat tersebut diantaranya adalah mudah digunakan, aman efektif dan efisien.Sistem informasi yang tidak memenuhi syarat-syarat tersebut bisa dikatakan bahwa sistem informasi tersebut tidak berhasil.Teknologi informasi dibuat dengan tujuan untuk membantu kehidupan kehidupan manusia supaya menjadi lebih mudah, efektif dan efisien.Demikian juga sistem informasi ditujukan untuk membantu kehidupan pekerjaan yang tadinya sulit, memakan banyak waktu dan tenaga bisa menjadi lebih cepat dikerjakan dan lebih mudah dengan adanya sistem informasi.

Sistem Informasi Manajemen Pendidikan (SIMDiK) Dinas pendidikan kabupaten Brebes merupakan sistem organisasi data untuk mengelola data pokok di lingkungan pendidikan Kabupaten Brebes yang dikerjakan secara online. SIMDiK online sudah digunakan kurang lebih selama lima tahun dan digunakan oleh tingkat satuan pendidikan di lingkungan dinas pendidikan kabupaten Brebes. Meskipun aplikasi SIMDiK sebagai sistem informasi yang bermanfaat, berdaya guna untuk pendataan data sekolah perlu adanya analisa web dari sisi Human Computer Interaction (HCI).

\section{METODE PENELITIAN}

Jenis penelitian yang dilakukan adalah penelitian asosiatif kausal. Menurut Umar (2003 : 30) penelitian asosiatif kausal adalah penelitian yang bertujuan untuk menganalisis hubungan antara satu variabel dengan variabel lainya atau bagaimana suatu variabel mempengaruhi variabel lain”.Sehingga langkah-langkah yang dilakukan dalam penelitian kausal adalah mengidentifikasi hubungan sebab akibat antar variabel, mencari tipe sesungguhnya dari fakta untuk membantu memahamidan memprediksi hubungan, menetapkan pendekatan kausal dari kejadian-kejadian yang berurutan dan mengukur variasi antara penyebab yang diduga dan akibat yang diduga. 


\section{METODE PENGUMPULAN DATA}

\section{a. Metode Kuesioner}

Pengumpulan data dilakukan dengan menggunakan kuesioner yaitu suatu metode pengumpulan data dengan menyebarkan daftar pertanyaan kepada petugas Dinas pendidikan kabupaten Brebes.Skala pengukuran dalam kuesioner memakai model skala Likert, yaitu skala yang dipakai untuk mengukur pendapat atau persepsi seseorang atau sekelompok orang.Jawaban diberi penilaian dari 1 sampai 5 Tanggapan yang paling positif (sangat setuju) diberi nilai paling besar dan tanggapan paling negatif (sangat tidak setuju) diberi nilai paling kecil.

\section{b. Studi Pustaka}

Studi pustaka atau studi literatur dalam penelitian ini menggunakan bahanbahan yang berkaitan dengan penelitian yang berasal dari jurnal-jurnal ilmiah, literatur-literatur, internet serta publikasi-publikasi lain yang layak dijadikan sumber masukan untuk penelitian.

\section{c. Observasi}

Proses pengamatan dan pencatatan pola perilaku subyek atau kejadian yang sistematis tanpa adanya pertanyaan atau komunikasi dengan individu yang diteliti.

\section{METODE ANALISIS DATA}

\section{1) Analisis Kuantitatif}

Analisis kuantitatif merupakan suatu pengukuran yang dapat dihitung atau pengukuran yang melibatkan jumlah satuan tertentu atau dinyatakan dengan angka-angka.Metode analisis yang dipilih adalah Regresi Linear bergandadengan bantuan software SPSS Versi 22 yang digunakan untuk menguji hipotesis H1 hingga $\mathrm{H} 4$.

\section{2) Skala Pengukuran}

Skala Likert digunakan untuk mengukur sikap, pendapat, persepsi seseorang atau kelompok orang tentang fenomena sosial. Skala Likert mempunyai gradasi dari sangat positif sampai dengan sangat negatif dimana sangat baik diberi 
skor 5, baik diberi skor 4, kurang baik diberi skor 3, tidak baik diberi skor 2 dan sangat tidak baik diberi skor 1 (Sugiyono, 2009).

\section{3) Uji Validitas}

Valid tidaknya suatu item dapat diketahui dengan membandingkan indeks korelasi Product moment(r hitung) dengan nilai kritis atau probabilitasnya. Dari rumus tersebut akan didapat nilai korelasi product moment, apabila nilai koefisien korelasi mempunyai taraf signifikasi $<0,05(\alpha=5 \%$ atau $r$ hitung $>r$ tabel (tingkat kepercayaan $95 \%, \alpha=5 \%$ ) maka item pertanyaan yang digunakan dalam instrumen tersebut valid.

\section{4) Uji Reliabilitas Instrumen}

Pengukuran reliabilitas adalah sejauh mana suatu hasilpengukuran relatif konstan apabila dilakukan pengukurankembali. Uji reliabilitas adalah tingkat kestabilan dari suatualat ukur dalam mengukur suatu gejala.Koefisien alpha atau cronbach alpha digunakan dalam penelitian untuk mengukur tingkat reliabilitas atau konsistensi internal diantara butir butir pernyataan dalam suatu instrumen penelitian.

\section{5) Uji F}

Untuk mengetahui tingkat signifikansi secara simultan atau bersama-sama pengaruh variabel independen terhadap variabel dependendigunakan uji.

\section{6) $\mathbf{U j i} \mathbf{T}$}

Untuk menguji tingkat signifikansi secara parsial apakah masing-masing variabel independen berpengaruh terhadapvariabel dependen digunakan uji t. 


\section{Alur Penelitian}

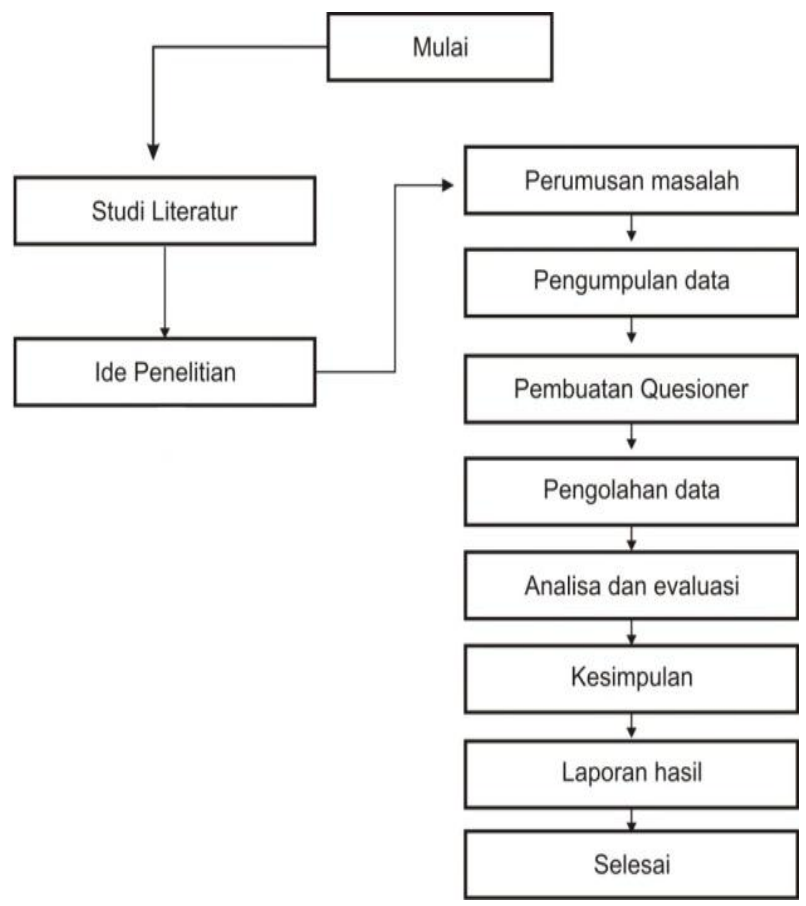

Gambar 1. Alur Penelitian

\section{ANALISIS HASIL}

\section{Uji Validitas dan Reliabilitas Instrumen}

Validasi instrumen dibuat untuk mendapatkan data yang valid sehingga instrumen tersebut dapat digunakan untuk mengukur apa yang seharusnya diukur. Validitas menunjukkan sejauh mana relevansi pertanyaan terhadap apa yang ditanyakan atau apa yang ingin diukur dalam penelitian. Validitas dan reliabilitas kuesioner diukur dengan melakukan pengujian kepada 15 responden. Hal ini dilakukan untuk untuk mengukur tentang valid dan tidak instrumen yang akan disebarkan pada responden. Berikut instrumen pertanyaan yang berkaitan dengan variabel penelitian usability, learnability, efficiency, memorability, error dan user satisfaction. 
Uji validitas menggunakan rumus uji korelasi Pearson Product Moment, dengan rumus:

Keterangan: $\quad \mathrm{r}=\frac{\mathrm{N}\left(\sum \mathrm{XY}\right)-\left(\sum \mathrm{X}\right)\left(\sum \mathrm{Y}\right)}{\sqrt{\left.\mathrm{N} \sum \mathrm{X}^{2}-\left(\sum \mathrm{X}\right)^{2}\right]\left[\mathrm{N} \sum \mathrm{Y}^{2}-\left(\sum \mathrm{Y}\right)^{2}\right]}}$

$\mathrm{r} \quad=$ korelasi antara $\mathrm{x}$ dengan $\mathrm{y}$

$\mathrm{n} \quad=$ jumlah sampel

$\sum \mathrm{X}=$ jumlah skor item

$\sum \mathrm{Y}=$ jumlah skor total item

Validitas kuesioner dilakukan dengan membandingkan nilai r-hitung dengan nilai r-tabel.Kaidah keputusan Jika r-hitung $>$-r-tabel berarti valid sebaliknya jika $r$-hitung $<r$-tabel berarti tidak valid. Pada uji validasi penelitian ini menggunakan responden dengan jumlah 15 orang, nilai r-tabel yaitu 0,514. Jadi butir pertanyaan akan dikatakan valid apabila nilainya lebih dari 0,514 dan jika kurang dari 0,514 maka butir pertanyaan tidak valid.

\section{Uji Reliabilitas Instrumen}

Instrumen yang reliabel berarti instrumen yang bila digunakan beberapa kali untuk mengukur objek yang sama akan menghasilkan hasil pengukuran yang sama. Hasil jawaban dari kuesioner diolah dengan uji statistik menggunakan program komputer. Uji reliabilitas menggunakan uji Alpha Cronbach, dengan rumus:

$$
r=\left[\frac{k}{k-1}\right]\left[1-\frac{\sum \sigma_{b}^{2}}{\sigma_{t}^{2}}\right]
$$

Keterangan :

ri $=$ Koefisein reliabilitas instrumen

$\mathrm{k}=$ banyaknya butir pertanyaan

$\Sigma \sigma_{\mathrm{b}}^{2}=$ total varians butir

$\sigma_{\mathrm{t}}^{2}=$ total varians 
Kriteria :

Jika nilai ri hitung > ri tabel maka alat ukur adalah reliabel Jika nilai ri hitung $\leq$ ri tabel maka alat ukur adalah tidak reliabel

Reliabilitas kuesioner diketahui dengan membandingkan nilai $r$ hitung dengan $r$ tabel, dimana nilai $r$ hitung yang digunakan adalah nilai Alpha. Dikatakan reliabel jika nilai $r$ hitung lebih besar dari nilai minimal reliabilitas yaitu 0,7. Uji reliabilitas menunjukkan bahwa kuesioner ini Sangat reliabel karena memiliki nilai lebih dari 0,7 yaitu 0,968

\section{Uji Normalisasi Data}

Uji normalitas data dimaksudkan untuk memperlihatkan bahwa data sampel berasal dari populasi yang berdistribusi normal. Pengujian ini adalah dengan mengamati nilai skewness data yang digunakan, apabila nilai CR pada skewness data berada padarentang antara +2.58 atau berada pada tingkat signifikansi 0.01.Hasil pengujian normalitas data ditampilkan pada tabel uji normalisasi data.

One-Sample Kolmogorov-Smirnov Test

\begin{tabular}{|c|c|c|c|c|c|c|c|}
\hline & & ussability & $\begin{array}{l}\text { learnabilit } \\
\text { y }\end{array}$ & $\begin{array}{l}\text { eficien } \\
\text { cy }\end{array}$ & $\begin{array}{l}\text { memor } \\
\text { ability }\end{array}$ & error & $\begin{array}{l}\text { User } \\
\text { satisfa } \\
\text { ction }\end{array}$ \\
\hline \multicolumn{2}{|l|}{$\mathrm{N}$} & 45 & 45 & 45 & 45 & 45 & 45 \\
\hline Normal & Mean & 21,58 & 36,91 & 27,09 & 12,18 & 38,76 & 39,38 \\
\hline Parameters ${ }^{a, b}$ & $\begin{array}{l}\text { Std. } \\
\text { Deviation }\end{array}$ & 2,251 & 3,801 & 2,983 & 1,353 & 4,518 & 4,886 \\
\hline Most Extreme & Absolute & ,225 & , 150 & , 180 & ,286 &, 115 & 096 \\
\hline \multirow[t]{2}{*}{ Differences } & Positive & ,225 &, 150 & , 180 & ,286 & ,101 & ,096 \\
\hline & Negative &,- 136 &,- 111 &,- 110 &,- 248 &,- 115 &,- 074 \\
\hline \multicolumn{2}{|l|}{ Test Statistic } & ,225 & ,150 & , 180 & ,286 &, 115 & ,096 \\
\hline \multicolumn{2}{|c|}{ Asymp. Sig. (2-tailed) } &, $000^{c}$ &, $012^{c}$ &, $001^{c}$ &, $000^{c}$ &, $160^{c}$ & $200^{c, d}$ \\
\hline
\end{tabular}
a. Test distribution is Normal.
b. Calculated from data.
C. Lilliefors Significance Correction.
d. This is a lower bound of the true significance. 
Berdasarkan uji normalitas dengan Kolmogorov-Smirnov Test diperoleh nilai Asymp.sig. untuk usability sebesar 0,000 lebih kecil dari 0,05 maka dapat disimpulkan bahwa data usability berdistribusi tidak normal, learnabilitysebesar 0,012 lebih besar dari 0,05 maka dapat disimpulkan bahwa data learnability berdistribusi normal, efficiency sebesar 0,001 lebih kecil dari 0,05 maka dapat disimpulkan bahwa data efficiency berdistribusi tidak normal, memorability sebesar 0,000 lebih kecil dari 0,05 maka dapat disimpulkan bahwa data memorability berdistribusi tidak normal, error sebesar 0,160 lebih besar dari 0,05 maka dapat disimpulkan bahwa data error berdistribusi normal dan user satisfaction sebesar 0,200 lebih besar dari 0,05 maka dapat disimpulkan bahwa data user satisfaction berdistribusi normal.

\section{Deskripsi Tanggapan Responden terhadap Variabel Penelitian}

Kategori untuk setiap item pertanyaan berdasarkan skor jawaban 1 sampai dengan 5 dapat diklasifikasi kelas dengan interval jarak kelas. Interval kelas dapat dicari dengan cara skor kategori jawaban tertinggi dikurangi skor kategori jawaban terendah, kemudian dibagi dengan jumlah kategori (Sangat Tinggi, Tinggi, Cukup, Rendah dan Sangat Rendah) . Untuk lebih jelasnya dapat dilihat pada perhitungan berikut :

$$
\frac{5-1=0,8}{5}
$$

Dari tanggapan masing-masing variabel diperoleh hasil dengan kategori tinggi. Hal ini menunjukkan bahwan SIMDiK efektif digunakan dalam pendataan data di satuan pendidikan di kabupaten Brebes

\section{Uji F}

Uji F digunakan untuk mengetahui pengaruh variabel bebas secara simultan berpengaruh signifikan terhadap variabel dependen. Langkah pengujian tersebut adalah sebagai berikut: 
1. Penentuan hipotesis

$\mathrm{H}_{0}: \mathrm{bj} \leq 0$ Tidak terdapat pengaruh secara simultan learnability, efficiency, memorability, error dan usersatisfaction terhadap usability

$\mathrm{H}_{\mathrm{a}}: \mathrm{bj}>0$ Terdapat pengaruh secara simultan learnability, efficiency, memorability, error dan usersatisfaction terhadap usability

2. Penentuan tingkat keyakinan

Derajat kepercayaan yang digunakan adalah 95 persen dengan $\alpha=0,05$.

3. Kriteria pengujian

$\mathrm{H}_{0}$ diterima jika $\mathrm{F}$ hitung $\leq \mathrm{F}$ tabel

$\mathrm{H}_{0}$ ditolak jika $\mathrm{F}$ hitung $>\mathrm{F}$ tabel

4. Menghitung nilai $\mathrm{F}$

Uji F dapat dihitung dengan software SPSS. Hasil uji F dapat dilihat pada Tabel 1.

Tabel 1. Hasil Uji__F

\begin{tabular}{|l|r|r|l|l|l|}
\hline Model & \multicolumn{1}{l|l|l|l|}{$\begin{array}{l}\text { Sum of } \\
\text { Squares }\end{array}$} & df & Square & F & Sig. \\
\hline 1 Regressio & 129,542 & 5 & 25,908 & 131,947 &, $000^{\mathrm{b}}$ \\
$\mathrm{n}$ & 7,658 & 39 &, 196 & & \\
Residual & 137,200 & 44 & & & \\
Total & & & & \\
\hline
\end{tabular}

5. Hasil pengujian

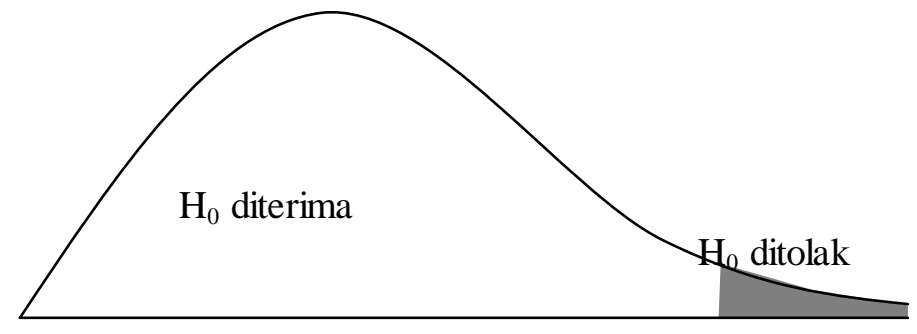

0

F tabel 2,4558 F hitung=131,947

Gambar 2. Kurva uji F 
Berdasarkan Tabel 1 dapat diketahui nilai $F$ hitung sebesar 131,947. Nilai $\mathrm{F}$ tabel pada tingkat keyakinan 95 persen $(\mathrm{Dfl}=5 ; \mathrm{df2}=39)$ sebesar 2,4558. Jadi $\mathrm{F}$ hitung $(131,947)$ lebih besar dari $\mathrm{F}$ tabel $(2,4558)$ dengan signifikansi $\mathrm{p}=0,000$, sehingga $\mathrm{H}_{0}$ ditolak dan menerima hipotesis alternatif yang menyatakan terdapat pengaruh secara simultan learnability, efficiency, memorability, error dan user satisfaction terhadap usability.

\section{Uji T}

Uji $\mathrm{t}$ digunakan untuk mengetahui pengaruh variabel learnability, efficiency, memorability, error dan user satisfaction terhadapusabilitysecara parsial. Langkah pengujian tersebut adalah sebagai berikut:

1. Penentuan hipotesis

$\mathrm{H}_{0}$ : bi $=0$ Tidak terdapat pengaruh secara parsial learnability, efficiency, memorability, error dan usersatisfaction terhadap usability

$\mathrm{H}_{\mathrm{a}}: \mathrm{bj} \neq 0$ Terdapat pengaruh secara parsial learnability, efficiency, memorability, error dan usersatisfaction terhadap usability

2. Penentuan tingkat keyakinan

Derajat kepercayaan yang digunakan adalah 95 persen dengan $\alpha=0,05$.

3. Kriteria pengujian

$\mathrm{H}_{0}$ diterima jika $-\mathrm{t}$ tabel $\leq \mathrm{t}$ hitung $\leq \mathrm{t}$ tabel

$\mathrm{H}_{0}$ ditolak jika $\mathrm{t}$ hitung < $-\mathrm{t}$ tabelatau $\mathrm{t}$ hitung $>\mathrm{t}$ tabel

4. Menghitung nilai $\mathrm{t}$

Uji $t$ dapat dihitung dengan software SPSS. Hasil uji $t$ dapat dilihat pada Tabel 2 . 
Tabel 2. Hasil Uji_t

\begin{tabular}{|l|l|l|l|l|}
\hline No & Variabel bebas & $\mathrm{t}$ & Sig. & Keterangan \\
\hline 1 & (Constant) & 1,041 & 0,304 & \\
2 & Learnability & $-6,346$ & 0,000 & Ho ditolak \\
3 & Efficiency & 14,024 & 0,000 & Ho ditolak \\
4 & Memorability & 2,317 & 0,026 & Ho ditolak \\
5 & Error & $-7,871$ & 0,000 & Ho ditolak \\
6 & User satisfaction & 6,886 & 0,000 & Ho ditolak \\
\hline
\end{tabular}

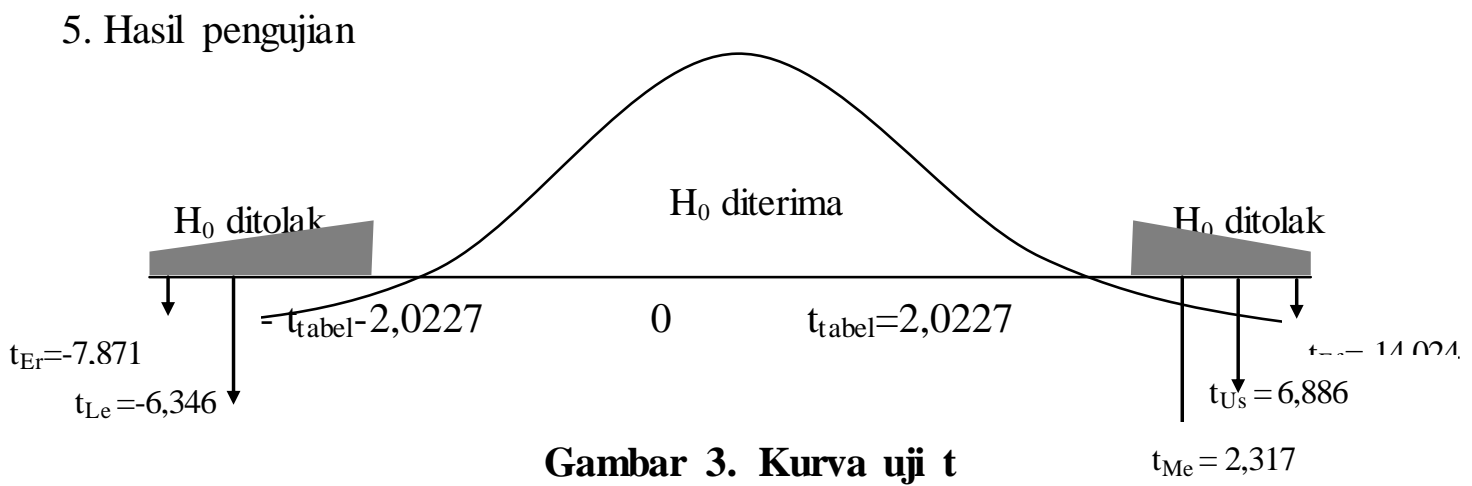

Berdasarkan Tabel 2 dan Gambar 3 dapat diketahui nilai t hitung variabel learnabilitysebesar -6,346. Nilai t tabel sebesar 2,0027. Jadi t hitung $(-6,346)<-\mathrm{t}$ tabel (-2,0227) dengan signifikansi $\mathrm{p}=0,000$, sehingga $\mathrm{t}$ hitung berada di daerah penolakan HO dan hipotesis alternatif diterima sehingga dapat diartikan terdapat pengaruh secara parsial learnability terhadap usability.

Nilai t hitung variabel efficiency sebesar 14,024. Nilai t tabel sebesar 2,0027. Jadi t hitung $(14,024)>\mathrm{t}$ tabel $(2,0227)$ dengan signifikansi $\mathrm{p}=0,000$, sehingga $\mathrm{t}$ hitung berada di daerah penolakan H0 dan hipotesis alternatif diterima sehingga dapat diartikan terdapat pengaruh secara parsial efficiency terhadap usability.

Nilai t hitung variabel memorability sebesar 2,317. Nilai t tabel sebesar 2,0027. Jadi $\mathrm{t}$ hitung $(2,317)>\mathrm{t}$ tabel $(2,0227)$ dengan signifikansi $\mathrm{p}=0,026$, sehingga $\mathrm{t}$ hitung berada di daerah penolakan $\mathrm{HO}$ dan hipotesis alternatif diterima 
sehingga dapat diartikan terdapat pengaruh secara parsial memorabilityterhadap usability.

Nilai t hitung variabel error sebesar -7,871. Nilai t tabel sebesar 2,0027. Jadi $t$ hitung $(-7,871)<-t$ tabel $(2,0227)$ dengan signifikansi $\mathrm{p}=0,000$, sehingga $\mathrm{t}$ hitung berada di daerah penolakan $\mathrm{H} 0$ dan hipotesis alternatif diterima sehingga dapat diartikan terdapat pengaruh secara parsial error terhadap usability.

Nilai t hitung variabel user satisfaction sebesar 6,886. Nilai t tabel sebesar 2,0027. Jadi $\mathrm{t}$ hitung $(6,886)>\mathrm{t}$ tabel $(2,0227)$ dengan signifikansi $\mathrm{p}=0,000$, sehingga $\mathrm{t}$ hitung berada di daerah penolakan $\mathrm{H} 0$ dan hipotesis alternatif diterima sehingga dapat diartikan terdapat pengaruh secara parsial user satisfactionterhadap usability.

\section{Persamaan regresi}

Hasil analisis regresi berupa persamaan regresi linier.Dalam penelitian ini regresi yang digunakan adalam analisis regresi linier berganda. Hasil analisis regresi dapat dilihat pada tabel 3 .

Tabel 3.Tabel Koefisien Regresi

\begin{tabular}{|l|r|r|r|}
\hline \multirow{2}{*}{ Model } & \multicolumn{2}{|c|}{$\begin{array}{l}\text { Unstandardized } \\
\text { Coefficients }\end{array}$} & $\begin{array}{l}\text { Standardized } \\
\text { Coefficients }\end{array}$ \\
\cline { 2 - 5 } & \multicolumn{1}{|c|}{$\begin{array}{l}\text { Std. } \\
\text { Error }\end{array}$} & \multicolumn{2}{|l|}{ Beta } \\
\hline (Constant) &, 862 &, 828 & \\
learnability &,- 573 &, 090 & $-1,232$ \\
eficiency & 1,316 &, 094 & 1,876 \\
memorability &, 204 &, 088 &, 154 \\
error &,- 502 &, 064 & $-1,276$ \\
User satisfaction &, 570 &, 083 & 1,450 \\
\hline
\end{tabular}

sebagai berikut:

$$
\mathrm{Y}=0,862-0,573 L e+1,316 E f+0,204 \mathrm{Me}-0,502 \mathrm{Er}+0,570 U s
$$




$$
\begin{aligned}
& \text { Keterangan }: \\
& \mathrm{Y}=\text { Usability } \\
& \mathrm{Le}=\text { Learnability } \\
& \mathrm{Ef}=\text { Eficiency } \\
& \mathrm{Me}=\text { Memorability } \\
& \mathrm{Er}=\text { Error } \\
& \mathrm{Us}=\text { User } \text { satisfaction }
\end{aligned}
$$

Nilai konstanta adalah sebesar 0,862, artinya nilai usabilitysebesar 0,862 jika variabel bebas yang terdiri atas learnability, efficiency, memorability, error dan usersatisfactionbernilai nol. Hal ini menunjukkan usability bernilai rendah jika tidak ada learnability, efficiency, memorability, error dan usersatisfaction .

Nilai koefisien regresi variabel learnabilityadalah -0,573.Nilai koefisien regresi tersebut negatif, artinya terdapat pengaruh negatif dari learnabilityterhadap usability.Pengaruh negatif tersebut berarti semakin tinggi learnabilitymaka akan semakin rendah usability.

Untuk koefisien regresi variabelefficiency adalah 1,316, nilai koefisien regresi tersebut positif, artinya terdapat pengaruh positif dari efficiency terhadap usability. Pengaruh positif tersebut berarti semakin tinggi efficiency maka akan semakin tinggi pula usability.

Untuk koefisien regresi variabelmemorability adalah 0,204, nilai koefisien regresi tersebut positif, artinya terdapat pengaruh positif dari memorabilityterhadap usability. Pengaruh positif tersebut berarti semakin tinggi memorabilitymaka akan semakin tinggi pula usability.

Nilai koefisien regresi variabel error adalah -0,502.Nilai koefisien regresi tersebut negatif, artinya terdapat pengaruh negatif dari error terhadap usability.Pengaruh negatif tersebut berarti semakin tinggi error maka akan semakin rendah usability.

Untuk koefisien regresi variabeluser satisfaction adalah 0,570 , nilai koefisien regresi tersebut positif, artinya terdapat pengaruh positif dari user satisfactionterhadap usability. Pengaruh positif tersebut berarti semakin tinggi user satisfactionmaka akan semakin tinggi pula usability. 


\section{KESIMPULAN}

1. Berdasarkan hasil jawaban responden dapat diketahuiSistem Informasi Manajemen Pendidikan (SIMDiK) Dinas Pendidikan Kabupaten Brebes sudah efektif.

2. Berdasarkan hasil analisis data dapat diketahui variabel-variabel yang berpengaruh terhadap usability, yaitu variabel learnability, efficiency, memorability, error danuser satisfaction, dengan penjabaran sebagai berikut :

1) Variabel learnability berpengaruh negatif secara parsial learnability terhadap usability. Hal ini berarti bahwa sebuah program yang semakin mudah dipelajari akan menurunkan penggunaan sistem (system use).

2) Variabel efficiency berpengaruh positif secara parsial terhadap usability. Hal ini berarti bahwa sebuah program yang semakin efisienakan meningkatkan penggunaan sistem (system use).

3) Variabel memorability berpengaruh positif secara parsial memorability terhadap usability. Hal ini berarti bahwa sebuah program yang semakin mudah diingat akan meningkatkan penggunaan sistem (system use).

4) Variabel error berpengaruh negatif secara parsial terhadap usability. Hal ini berarti bahwa sebuah program yang semakin banyak errornya akan menurunkan penggunaan sistem (system use).

5) Variabel user satisfaction berpengaruh positif secara parsial terhadap usability. Hal ini berarti bahwa sebuah program yang semakin membuat pengguna puas akan meningkatkan penggunaan sistem (system use).

\section{SARAN}

1. Perlunya pengembangan aplikasi dalam kemudahan pengunaan dan arti dari simbol yang ada dalam sistem sehingga meningkatkan kualitas sistem, kualitas informasi dan kualitas layanan sehingga mempengaruhi penggunaan sistem yang baik. Dimana system ini hendaknya bisa terintegrasi dengan Data 
Pokok Pendidik (Dapodik) Kemendikbud sehingga pengolahan data sekolah tidak harus dilakukan berulang-ulang.

2. Penelitian yang sama dapat dilakukan terhadap unit utama lainnya di lingkungan Dinas Pendidikan Kabupaten Brebes dengan menggunakan model yang sama, atau dengan jumlah sampel yang lebih besar.

3. Bagi peneliti selanjutnya dapat melakukan evaluasi keberhasilan sistem informasi terhadap sistem-sistem lainnya khususnya sistem informasi yang wajib digunakan pada suatu institusi, dengan penambahan variabel atau jumlah sampel yang lebih besar.

\section{DAFTAR PUSTAKA}

Arikunto, 2013, Manajemen Penelitian, Rineka Cipta, Jakarta

Umar Husein, 2003, Metodologi Penelitian Untuk Skripsi dan Tesis, PT. Gramedia Pustaka, Jakarta

Nielsen, Jacob.,1994, "Guerrilla HCI : Using Discount Usability Engineering to Penetrate the Intimidation Barrier" [online], Available: http://www.useit.com/paper/guerrilla_hci.html, [2008, Januari].

Sugiyono, 2009, Statistik Untuk Penelitian, CV Alfabeta, Bandung

Al-Fatta, 2007, Analisis Perancangan Sistem Informasi, Andi Ofset, Yogyakarta

Jogiyanto, 1999. Analisis dan Desain Sistem., Andi.Yogyakarta

Sutanta, Edhy, 2006, Sistem Basis Data, Andi Offset, Yogyakarta

Al-Fatta, 2007, Analisis Perancangan Sistem Informasi, Andi Ofset, Yogyakarta

Sutabri, Tata, 2007, Analisis dan Perancangan Sistem Informasi, Andi Offset, Yogyakarta

Jogiyanto, 1999. Analis is dan Desain Sistem., Andi.Yogyakarta

Fakhreddine Karray, Milad Alemzadeh, Jamil Abou Saleh and Mo Nours Arab Pattern Analysis and Machine Intelligence Lab.,Departemen of Electrical and Computer Enginering University of Waterloo, Waterloo, Canada March. 2008

Sastramihardja HS., Perancangan Kerja dalam Perangkat Lunak, Interaktif, Jurnal Informatika ITB, 1999. 
Nielsen, J.,2003 Usability 101 : Introduction to usability”, Useit.com: Usable Information Technology, UseNet Alertbox, available at :www.useit.com/alertbox/20030825.html diakes tanggal 20 Maret 2014.

Jonathan W Palmer, “Web Site Usability, Design and Performance Metrics", Information Systems Research,pg 151; ABI/INFORM Global, June 2002

Norman, D.A, Draper, S.W., 1986. Cognitive engineering'.in:Norman, D.A.,Draper,S.W.(Eds),User -Centered -Sistem Design: Perspective on Human-Computer-Interaction, Lawrence $\mathrm{El}$ Associates Publishers, Hillsdale,NJ.

Sudarmawan,Dony,A., 2007. Interaksi Manusia dan Komputer. Andi Offset : Yogyakarta.

Valarich, George, Hoffer, 2001, Essentials of System Analysis and Design, Pretice Hall

Su, Bude, Bonk, Curtis J., Magjuka, Richard J., Liu,Xiaojing., Lee, Seung-hee, 2005, The Infortance of Interaction in Web-Based Education : A Program Level Case Study of Online MBA Courses, Journal of Interactive Online Learning

Nielsen, J.,2003 Usability 101 : Introduction to usability”, Useit.com: Usable Information Technology, UseNet Alertbox, available at :www.useit.com/alertbox/20030825.html diakes tanggal 20 Maret 2014.

Yohanes Anton Nugroho ,2011, It's Easy Olah Data dengan SPSS, diterbitkan oleh Skripta Media Creative (PT.Insan Madan iGroup).ISBN978-6029025-36-11 Cetakan 1 - Agustus 2011 